\title{
A Study of Students' Perception: Identifying EFL Learners' Problems in Speaking Skill
}

\author{
${ }^{* 1}$ Ikrar Genidal Riadil \\ ${ }^{1}$ Universitas Tidar, Magelang, Indonesia \\ ${ }^{*}$ Corresponding Author: $\underline{\text { ikrargenidal21@gmail.com }}$
}

\author{
Submitted: 25/04/2020 Revised: 17/05/2020 Accepted: 22/05/2020
}

How to cite this article: Riadil, I. G. (2020). A study of students' perception: Identifying EFL Learners' problems in speaking skill. IJELR: International Journal of Education, Language, and Religion, 2(1), 25-30. http://doi.org/10.35308/ijelr.v2i1.2256

\begin{abstract}
Language is a pivotal aspect of human being. By learning, language people can communicate with each other, get information from one to another and interact. Unfortunately, in the real condition, it is still difficult for Indonesian students to practice their English ability in daily conversation. This paper will discuss the student's perception within implementation problems and its solutions. The aim of this study is to identify the speaking problems experienced by EFL learners in speaking English. The researcher conducted this study using the qualitative research method. To gather the results, the researcher uses a questionnaire centered on the Penny Tang (1997) on speaking problems in learning a foreign language. The study's data is collected from thirtyfive students from Tidar University in Magelang. The result of the study is that the students have problems in learning speaking English. The most problematic for the students is mother tongue use, 77\% students use their other tongue in English class and 83\% agree that mother tongue is easier than English.
\end{abstract}

\section{Keywords}

Students' perception; English learning; Speaking skill; Speaking problems

\section{Introduction}

Language is an important aspect of human being. By learning, language people can communicate with each other, get information from one to another and interact. Language has a big role in human life to make a relation in their environment. One of the experts' states that language is used widely in communication between people who do not share the same first (or even second) language (Harmer, 2007). It indicates that language is very crucial to learn in human life.

English appears as one of international languages used to communicate among people all over the world. The use of English in nonnative country can be divided into two English as the second language and English as foreign language (EFL). One of the countries who applied English as foreign language is Indonesia. In EFL country, English is used for some purposes such as education, business, etc. Related to the education function, English is taught in the school started from elementary school. 
Unfortunately, in the real condition, it is still difficult for Indonesian students to practice their English ability in daily conversation even though they have been studying English for ten years in formal junior high school, senior high school and university due to they might get a good score of English in their report card but they cannot speak English fluently yet (Musthafa, 2001). It is the fact that many English as a Foreign Language (EFL) teachers complain about their speaking classes in which a considerable number of students are not responding actively in speaking exercises (Abadi, 2015)

Many factors may affect students negatively in taking part in speaking activities during the teaching experience. First, the large numbers of students which usually consist of 30-35 students or more become problematic. Such section provides fewer opportunities for them to practice speaking. Richards \& Schmidt (2010) states that class size affects the quality of instruction in which it should not exceed fifteen for most language classes.

Second, students tend to conceal their mistakes and weakness to protect them from being laughed at. As a result, they are unwilling to speak English. So, the less they practice, the less they improve their speaking skills and the more they are afraid of doing so. Last, most teachers prefer teaching grammar to productive skills such as speaking and writing. This is supported by Musthafa (2001) explained that many teachers in Asia tend to focus their teaching on grammatical items and knowledge of syntax.

In this era many students of English Department at Tidar University still shy to speak English on campus. Some of them only speak English in a special event. Sometimes, they speak English to their lecturers. Some students also speak English with their certain friends in the English Department.

In learning English, there are four skills should be mastered by the learners. They are listening, speaking, reading, and writing. All of them are important and interrelated each other. Tang (1997:120) stated in her book untitled "A Course in Language Teaching: Practice in Theory" stated that among the four skill (listening, speaking, reading, and writing), speaking is the most important skills cause when speaking, someone is having background knowledge an also many of foreign language learners are interesting in learning speaking. From her point of view, it is stated that speaking is the most essential skill rather than the others skills because someone who are able to speak in foreign language means that she/he is knowledgeable. Moreover, according to Nur \& Riadil (2019) as cited from (swary, 2014), the researcher infers that speaking also beneficial in giving us a useful valuable skill which help us to contribute in the community or even our country.

Seeing the important of speaking skills of the foreign language in this paper in English, English learners should be able to speak English confidently and well. However, in the reality, there are a lot of English learners face the problem in speaking. Speaking problems are problems that affect someone to the poor speaking performance. Riadil (2019) stated language problems can affect to the poor academic performance of the students. Students who are poor in speaking ability tend to the lack of vocabularies, grammar, and pronunciation in which belong to linguistics problems. Those problems disturb students in improving their speaking ability. Another problem which influences the students' speaking ability is psychological problem is psychological problems which the problems that related to the emotional and physical condition and self-productivity such as lack of self-confident, nervous, feeling shy when speaking English. Tang (1997: 121) mentioned that there are some problems in speaking activities namely: inhibition, nothing to say, low or uneven participation and mother tongue use.

\section{a) Inhibition}


Different with reading, writing and listening, speaking needs some degree of real-time to an audience. Students are often inhibited in trying to say something in a foreign language in the class because of worry in making mistakes, afraid of getting criticism, feel shy to speak in foreign language.

\section{b) Nothing to Say}

Students often complain that they cannot say anything. They also do not have motivation to express themselves.

\section{c) Low or Uneven Participation}

In a group of students, there will be someone who talks the most to be heard while the others do not have or even have a little opportunity to speak. This condition causes the tendency of being dominance than the other.

\section{d) Mother-Tongue Usage}

In the realm of education such as school and university, the learners mostly come from the same area that uses some mother tongue. It leads them to use it in communicating each other because it is easier and flow naturally than the foreign language.

Brown (2007) stated in his book entitled "Teaching by Principles: An Interactive Approach To Language Pedagogy" that there are eight cases in which speaking is difficult, they are: clustering, redundancy, reduced form, performance variable, colloquial language, rate of delivery, stress, rhythm, and intonation, and the last is interaction. Based on these phenomena, the researcher is interested in analyzing some problems related to the phenomena. Nevertheless, in this paper, the researcher conducts the research using Ur theory to answer the research questions: (1) what are the EFL learners' problems in speaking English?

\section{Method}

Qualitative research is used in this research. Patton \& Cochran (2007) explained that qualitative research is characterized by its aims, which relate to understanding some aspect of social life, and its methods which generate words, rather than numbers, as data for analysis. Qualitative research is understanding of social phenomenon based on participant's point of view. In order to increase information into a certain phenomenon, such as an environment, a process, or a belief. The data are collected by giving questionnaires to participants. The data collection procedures of this study were started by giving the questionnaire, asking the participants to fill in the questionnaire and finally the researcher compiled the questionnaire that had been answered.

This method is influenced by Cam \& Tran (2017) After the data have collected, it will be analyzed and recognized. Like what Cam \& Tran (2017) stated that the questionnaire is a quite useful collection method because researcher can reach many participants and respondents in a short time and it does not need cost so much.

Therefore, the researcher used the random sampling technique to get the data. The questionnaire is delivered to Tidar University students as EFL learners in Magelang randomly. The instrument used in 
the study is adapted from Ur theory about problems in speaking which is cited from (Swary, 2014). The questionnaire was chosen by adopting the research from (Tang, 1997). This questionnaire consists of eight questions which is related to the speaking problem introduced by Tang (1997) with three of choices those are; often, seldom, and never in each number. Those choices are response to the intensity of the students' problem in speaking English. The questionnaire was distributed to the Tidar University students as EFL learners in Magelang.

In doing the research, the researcher uses descriptive studies. To collect the data, the researcher spread the questionnaires to the EFL learners. In order to find out EFL learners' points of view on their ways in speaking the English language learning, a structured questionnaire was given to the participants. and follow these steps: (1) Determine the topic will be conducted. (2) Select a case related to the students' problem in speaking English. (3) Create the instruments. In this study, the researcher uses questionnaire. (4) Deliver the questionnaire to the subject of the study. (5) Collecting data and examine the data taken from the subject of the study.

As for this research method, the authors carried out the following steps:

The arrangement of this study consists of:

1. Research Subject

The research subjects were students in English Department Students Tidar Magelang University, Central Java with thirty-five respondents.

2. Research Place

The study was conducted at Tidar University Magelang, Central Java.

3. Research Time

This research was conducted in the year of 2020 .

Besides that, the questions which given are in the English language although some reason that respondents answered are in Indonesian. Even though it does not impact the research. Besides, they could express their feeling easily and free. Not only that the questionnaire does not let the respondents write their real name. They could write their real name or the initial. Then the researcher will name them as respondent one, two, and so on and it does not impact the data that have collected.

\section{Results}

The questionnaire is responded by thirty-five students from Tidar University students as EFL learners in Magelang. The result of the data collected from the questionnaire which has been distributed is in following table.

Table 1. The questionnaire result of EFL learners

\begin{tabular}{llcccc} 
& & \multicolumn{3}{c}{ Intensity } & \multirow{2}{*}{ Total } \\
\cline { 3 - 5 } No & Speaking problem & Often & Seldom & \multirow{2}{*}{ Never } & \\
\hline 1. & Inhibition & $39 \%$ & $32 \%$ & $29 \%$ & $100 \%$ \\
2. & Nothing to say & $39 \%$ & $34 \%$ & $27 \%$ & $100 \%$
\end{tabular}


3. Low or uneven participation

4. Mother tongue use
$14 \%$

$80 \%$
$69 \%$

$17 \%$
$17 \%$

$100 \%$

$3 \%$

The table above will be more explained in detail below. In every point about speaking problem faced by the student's in Tidar University students as EFL learners in Magelang, there are some questions should be answered by the respondents.

\section{Inhibitions}

Inhibition is speaking problems which are related to the students' worries when they are speaking in English. The aspects in this speaking problems including students' worry in making mistakes in pronunciation, grammar, body language, or lexical items they use to express something, worry about being criticism, and feeling shy when speaking English. The data presented on the table below.

Table 2 The Inhibitions section result of EFL learners' perception

\begin{tabular}{ccccc} 
& Speaking problem & \multicolumn{3}{c}{ Intensity } \\
\cline { 3 - 5 } No & Worry about making mistakes & Often & Seldom & Never \\
\hline 1. & & $60 \%$ & $26 \%$ & $14 \%$ \\
2. & Worry about being criticism & $31 \%$ & $49 \%$ & $20 \%$ \\
3. & Feeling shy & $26 \%$ & $23 \%$ & $51 \%$ \\
\hline
\end{tabular}

Based on the result, students are having problem towards all points I inhibitions. The first aspect is worry about making mistakes when speaking English shows that about $86 \%$ of the respondents ever experienced in this problem. Meanwhile, only $14 \%$ who are never faced this problem.

Next aspect in inhibition is worry about being critic. There are 11 students or $31 \%$ are afraid for being criticism by other people when they are speaking English. $49 \%$ of the respondents sometimes are afraid, but only 7 students or $20 \%$ who are brave enough for getting criticism from other people.

The last aspect regarded with inhibition is feeling shy. Among the respondents, 9 students (26\%) are feeling shy to speak English, 8 students sometimes feel it, and 18 students (51\%) are confident enough in speaking English.

The finding of this research shows that students' problems related to the inhibition still need more attention. Students are afraid to speak English because they are concern about the grammatical structure, pronunciation, and vocabulary. They are worried when they are speaking English, the other students will criticize their performance. Meanwhile, based on the finding, the researcher found that almost of the respondents are having same problems means that they have same position or knowledge in which never be realized the student itself. Students tend to think that she/he is the worst, indeed they are in the same level. 
On the other hand, the researcher found a positive behaviour toward students' confident in speaking English. Although there are some respondents who still feel shy in speaking English, but more than a-half of the respondents are confident to when they are speaking English.

The finding is matched with theory from Penny Tang (1997) which stated that inhibition -worry in making mistakes and worry to be criticism- is students' speaking problem. However, the study found that most of respondents do not shy when they are speaking English.

\section{Nothing to Say}

Table 3 The section of "Nothing to Say" result of EFL learners' perception

\begin{tabular}{ccccc} 
& & Speaking problem & \multicolumn{3}{c}{ Intensity } \\
\cline { 3 - 5 } No & & Often & Seldom & Never \\
\hline 1. & Lack of topical knowledge & $66 \%$ & $31 \%$ & $3 \%$ \\
2. & Don't have motivation & $11 \%$ & $37 \%$ & $52 \%$ \\
\hline
\end{tabular}

Based on the result, students are having problem towards all points of nothing to say. The result shows that $97 \%$ of the respondents are lack of topical knowledge. Meanwhile, only $3 \%$ who are never faced this problem.

Next aspect is about having motivation to speak English. There are 4 students or $11 \%$ of the respondents who do not motivate to speak English. 37\% of the respondents sometimes get it, and 18 students or $52 \%$ are motivated to be able to speak English.

The finding shows that students are facing problems in both of the aspects in nothing to say. Almost two-third of the respondents stated that they are lacking of topical knowledge when talking with the others using English. Students who do not know about the topic they are talking about tend to keep silent and just listening to other. It is matched from an expert Tang (1997) believed that learners tend to keep silent on which the topic chosen by the teacher is not familiar for them or they only know a little.

\section{Low or Uneven Participation}

Low or uneven participation tend to the students' frequency in participating in speaking English in the class.

Table 4 The section of "Low or Uneven Participation" result of EFL learners' perception

\begin{tabular}{llccc} 
& \multirow{2}{*}{ No } & Speaking problem & \multicolumn{3}{c}{ Intensity } \\
\cline { 3 - 5 } & & Often & Seldom & Never \\
\hline 1. & Low and uneven participation & $14 \%$ & $69 \%$ & $17 \%$ \\
\hline
\end{tabular}


Based on the result, it shows that $69 \%$ of the respondents are rarely participating in their class. Even $17 \%$ never participate and only $14 \%$ who often participate in their class.

The result shows that most of the respondents are low and uneven participation problems. The data above is suitable with (Tang, 1997). In addition, that different opportunity of students in speaking English lead to the tendency of some students to dominate the class.

\section{Mother Tongue Use}

Table 5 The section of "Mother Tongue Use" result of EFL learners' perception

\begin{tabular}{ccccc} 
& & & \multicolumn{2}{c}{ Intensity } \\
\cline { 3 - 5 } No & Speaking problem & Often & Seldom & Never \\
\hline 1. & The students' use mother tongue & $77 \%$ & $17 \%$ & $6 \%$ \\
$2 . \quad \begin{array}{l}\text { The students feel that mother } \\
\text { tongue is easier }\end{array}$ & $83 \%$ & $17 \%$ & $0 \%$ \\
\hline
\end{tabular}

Based on the result, 77\% students are using their mother tongue in their English class. Only 6\% who use English in the class and the rest are sometimes in English sometimes in mother tongue. Next, $83 \%$ of the respondents agree that mother tongue is easier than English. No one student feels that English is easier.

The students are often using their mother lounge in English class. Only 6\% of the respondents who are never use their mother tongue in their English class. The, no one of the respondents who feel English is easier than mother tongue. It means that English learners still found that English is hard for them. These problems occur because of students' lack of the English vocabularies, topical knowledge and their frequency in speaking English. It is different with their mother tongue which has been acquired since their childhood and used for communication in their daily life.

\section{Conclusion}

Students of Tidar University as EFL learners face problems in learning speaking English. The problems are inhibition, nothing to say, low or uneven participation, and mother tongue use. In inhibition aspect, students are worry in making mistake and being criticism. Students concern about their pronunciation, grammatical structure, and vocabularies that make them afraid to be criticism by the others. However, most of the students are confident to speak English even though they have concern. Then, students have lack topical knowledge which lead them to the low or uneven participation in their class. Meanwhile, they are motivated to be able to speak English. Students find that mother tongue is easier than English which lead them to use mother tongue mostly in the English class.

\section{Acknowledgement}


Praise the author pray to Allah SWT because of the grace, the author can complete a research article journal entitled " A Study of Students' Perception: Identifying EFL Learners' Problems in Speaking Skill" on time. I am enormously grateful to all of my parents, friends, relatives, and colleagues for the continuous encouragement, kindly advices throughout my study and have been giving me the warm support, inspiration, support, and thoughtful guidance. The writer and journal article got a plenty of help, guidance and support from various parties so that with humility the authors express their deepest gratitude to all of my parents, friends, relatives, and colleagues who have helped the author.

\section{References}

Abadi, C. P. (2015). Developing Speaking Skill in EFL English Course. Journal on English as a Foreign Language, 5(2), 133. https://doi.org/10.23971/jefl.v5i2.373

Brown, H. D. (2007). Teaching by Principles, Second Edition. Teaching by Principles An Interactive Approach to Language Pedagogy.

Cam, L., \& Tran, T. M. T. (2017). An evaluation of using games in teaching English grammar for first year English-majored students at Dong Nai Technology University. International Journal of Learning, Teaching and Educational Research, 16(7), 55-71. Retrieved from https://pdfs.semanticscholar.org/ea44/48f1c6cbb8dab7420abbd20a993a86728206.pdf

Harmer, J. (2007). The Practice of English Languag Teaching. 394-409.

Musthafa, B. (2001). Communicative language teaching in Indonesia issue of theoretical assumption and challenges in the classroom practice. Journal of Southeast Asian Education, 2.

Nur, M. R. O., \& Riadil, I. G. (2019, May). SEESAW MEDIA: DIGITAL NATIVES'PREFERENCE IN 4.0 SPEAKING LEARNING CLASS. In English Language and Literature International Conference (ELLiC) Proceedings (Vol. 3, pp. 202-208).

Patton, M., \& Cochran, M. (2007). A Guide to Using Qualitative Research Methodology. In Medecins Sans Frontieres. Retrieved from http://msf.openrepository.com/msf/handle/10144/84230

Riadil, I. G. (2019). The EFL Learner's Perspectives About Accuracy, Fluency, and Complexity in Daily Routines. Journal of Research on Applied Linguistics, Language, and Language Teaching, 2(2), 160-166. https://doi.org/https://doi.org/10.31002/jrlt.v2i2.652

Richards, J. C., \& Schmidt, R. (2010). Longman dictionary of language teaching \& applied linguistics. In Proceedings of the 21st Asian Pacific Weed Science Society (APWSS) Conference, 2-6 October 2007, Colombo, Sri Lanka. Retrieved from http://images.pcmac.org/Uploads/JeffersonCountySchools/JeffersonCountySchools/Departments/ DocumentsSubCategories/Documents/English - Dictionary of Language Teaching and Applied Linguistics.pdf

Swary, D. (2014). A Study of Students ' Problems in Learning Speaking English At the Second Grade of Faculty of Tarbiyah and Teaching Science of Syekh Nurjati State Institute for Islamic Studies. Thesis, (Problem In Learning Speaking), 67.

Tang, F. (1997). A course in language teaching: Practice and theory. System. https://doi.org/10.1016/s0346-251x(97)84229-7 